\title{
PENGARUH MOTIVASI BERPRESTASI \\ TERHADAP KESIAPAN BELAJAR, PELAKSANAAN PRAKERIN \\ DAN PENCAPAIAN KOMPETENSI MATA PELAJARAN PRODUKTIF
}

\author{
Rudy Fatchurrochman \\ SMKN 1 Jatibarang, \\ Jl. Raya Jatisawit-Jatibarang, Jatibarang, Kab. Indramayu 45273 \\ rudyfatcurrochman@yahoo.com
}

\begin{abstract}
Abstrak: Penelitian ini bertujuan untuk mendefinisikan faktor yang mempengaruhi pencapaian kompetensi mata pelajaran produktif TKR, mendeskripsikan tentang motivasi berprestasi, kesiapan belajar, dan pelaksanaan prakerin dalam kaitan dengan pencapaian mata pelajaran produktif, dan untuk mengetahui pengaruh kesiapan belajar dan pelaksanaan prakerin terhadap pencapaian kompetensi mata pelajaran produktif TKR. Hasil pengolahan korelasi dan koefisien determinasi diperoleh motivasi berprestasi terhadap kesiapan belajar berkorelasi tinggi sebesar 0,875 dan terhadap pelaksanaan prakerin berkorelasi sebesar 0,678. Kesiapan belajar terhadap pencapaian kompetensi mata pelajaran produktif berkorelasi sebesar 0,392. Pelaksanaan prakerin berkorelasi sebesar 0,381 terhadap pencapaian kompetensi mata pelajaran produktif. Kesiapan belajar dan pelaksanaan prakerin berkorelasi sebesar 0,418. Kesimpulan dari penelitian ini yaitu adanya pengaruh yang signifikan antara motivasi berprestasi dengan kesiapan belajar dan pelaksanaan prakerin, sehingga perlu adanya peningkatan motivasi dari siswa. Khususnya motivasi berprestasi supaya tingkat kesiapan siswa dalam belajar lebih baik dan dalam pelaksanaan prakerin juga lebih meningkat.
\end{abstract}

Kata kunci: kesiapan belajar, prakerin, kompetensi, pelajaran produktif

Abstract: This study aims to define the factors that influence the achievement of productive subjects competence in TKR (Light Vehicle Engineering), describe the achievement motivation, learning readiness, and Prakerin or OJT (On Job Training) implementation in connection with the achievement of productive subjects, to determine the effect of achievement motivation on learning readiness and OJT implementation, and to determine the effect of learning readiness and OJT implementation on the competence achievement of productive TKR subjects. The calculation results of correlation and coefficient of determination show that achievement motivation correlates to learning readiness by 0,875 , and to OJT implementation by 0,678. Learning readiness correlates to competence achievement of productive subjects by 0,392; OJT implementation correlates to the competence achievement of productive subjects by 0,381 ; while learning readiness and OJT implementation are correlated by 0,418. The study concludes that there is a significant correlation between achievement motivation, learning readiness and OJT implementation, and therefore there is a need to enhance students' motivation, especially achievement motivation, so that students' can have better level of learning readiness and OJT implementation.

Keywords: learning readiness, prakerin (OJT), competence, productive subjects

\section{PENDAHULUAN}

Keberhasilan pendidikan kejuruan tidak hanya tergantung pada pendidik yang selalu dituntut dapat mengajar secara profesional saja. Melainkan peran aktif siswa di dalam proses belajar juga sangat menentukan keberhasilan proses pendidikan. Belajar merupakan suatu proses dari seorang individu yang berupaya mencapai tujuan belajar atau yang biasa disebut hasil belajar. Dimana hasil belajar merupakan bentuk perubahan perilaku yang relatif menetap. Oleh karena itu, untuk mendapatkan hasil belajar yang baik dan maksimal diperlukan persiapan siswa dalam belajar yang baik pula. Persiapan siswa dalam belajar merupakan kebutuhan pokok yang harus dipenuhi oleh siswa dalam mencapai hasil belajar. Menurut Djamarah (2002:35), "kesiapan untuk belajar jangan hanya diterjemahkan siap 
dalam arti fisik, tetapi juga diartikan dalam arti psikis dan materil”. Kesiapan fisik misalnya kondisi badan yang sehat dan bugar. Kesiapan psikis misalnya ada hasrat untuk belajar, dapat berkonsentrasi, dan ada motivasi instrinsik. Kesiapan materil misalnya ada bahan yang dipelajari atau dikerjakan berupa buku bacaan, catatan pelajaran, modul dan job sheet untuk pembelajaran praktek. Kesiapan siswa dalam belajar merupakan kondisi diri siswa yang telah dipersiapkan untuk melakukan suatu kegiatan belajar. Kesiapan diri siswa akan melahirkan perjuangan untuk mencapai apa yang dicita-citakan.

Faktor eksternal yang menunjang keberhasilan penguasaan kompetensi keahlian di SMK salah satunya adalah program praktek kerja industri. Program pembelajaran di industri ini akan mengantarkan siswanya mengenal jenis pekerjaan yang sesuai dengan kompetensi keahliannya. Melalui penghayatan dalam program praktek kerja industri, siswa akan memperoleh pengalaman bernilai yang akan berpengaruh secara positif yang akhirnya akan membantu meningkatkan kompetensi sesuai bidang keahliannya (Nolker, 1983: 119). Agar tujuan prakerin tepat sasaran, maka diperlukan pemetaan yang matang antara kompetensi di sekolah dikaitkan dengan kompetensi di dunia kerja. Pemetaan dunia industri yang sesuai dengan kompetensi keahlian yang dipelajari siswa. Program monitoring dan evaluasi harus terencana dan terarah. Selain program prakerin faktor eksternal yang juga mempengaruhi adalah layanan pembelajaran, fasilitas sekolah, lingkungan, dan faktor keluarga.

Faktor internal lain yang memberikan pengaruh positif terhadap proses pembelajaran adalah adanya motivasi berprestasi dari siswa. Motivasi berprestasi adalah kesungguhan atau daya dorong seseorang untuk berbuat lebih baik dari apa yang pernah dibuat atau diraih sebelumnya maupun yang dibuat atau diraih orang lain. Dalam pembelajaran peran motivasi berprestasi ini berperan penting dalam menunjang keberhasilan. Seseorang yang memiliki motivasi berprestasi yang kuat cenderung akan melakukan berbagai upaya untuk dapat menguasai bidang yang dipelajarinya. Sehingga peran motivasi berprestasi menjadi penting bagi siswa SMK dalam mempersiapkan proses belajar ataupun dalam pelaksanaan prakerin. Implikasinya pada pencapaian kompetensi produktif yang dipelajarinya sebagai persiapan memasuki dunia kerja.

Kenyataannya tidak semua siswa SMK maupun lembaga pendidikan kejuruan mampu melaksanakan sesuai dengan ketentuan, termasuk yang dijumpai di SMK Negeri 1 Jatibarang. Kondisi tersebut bisa dilihat dari beberapa fakta terkait dengan kondisi motivasi berprestasi. Kesiapan belajar siswa, dan pelaksanaan praktek kerja industri memiliki hubungan dengan pencapaian kompetensi mata pelajaran teknik kendaraan ringan.

Di lihat dari faktor internal siswa, yaitu kesiapan belajar dan motivasi berprestasi siswa dalam mengikuti pembelajaran produktif juga dirasakan oleh penulis masih belum 
merata. Kondisi ini bisa dilihat dari keadaan siswa yang belum memiliki kesiapan dalam mengikuti pembelajaran baik dari faktor fisik, psikis maupun materil. Indikasinya adalah masih terdapat siswa yang kurang siap dalam mengikuti pelajaran. Hal ini bisa dilihat dari prilaku siswa yang datang terlambat, mengantuk, lesu, kurang konsentrasi, dan kurang serius dalam mengikuti pembelajaran produktif, juga masih ditemui beberapa siswa yang tidak mempersiapkan bahan pelajaran atau modul, tidak membuat dan mempelajari job sheet. Dalam membuat tugas mengambil jalan pintas dengan menyalin hasil pekerjaan temannya, sehingga hal ini akan menghambat kelancaran dalam pembelajaran praktek.

Dalam hal motivasi berprestasi dorongan dari dalam diri siswa untuk berusaha menguasai pembelajaran praktik dan memperoleh hasil yang lebih baik juga dirasakan belum merata. Dalam artian masih ada beberapa siswa yang belum memiliki hasrat atau keinginan kuat untuk belajar dan menjadi lebih baik. Tanggung jawab terhadap penyelesaian tugas dan praktek masih kurang, dan ada beberapa siswa yang memilih kompetensi keahlian teknik kendaraan ringan karena mengikuti teman-temannya.

Sedangkan dalam pelaksanaan Praktek Kerja Industri (Prakerin) kendala yang masih dijumpai adalah dalam pengiriman siswa ke industri. Pengiriman tanpa dilakukan secara bersama dengan industri melalui jaringan kerjasama yang mengikat dan kajian kurikulum yang lebih mendalam. Manajemen sekolah perlu mempertimbangkan kembali program praktek kerja industri melalui prakerin dengan melakukan kajian antara kompetensi di sekolah disesuaikan dengan dunia kerja melalui pemetaan industri. Sehingga para siswa bisa melaksanakan prakerin yang sesuai dengan bidang keahliannya. Siswa sendiri dalam melaksanakan kegiatan prakerin masih belum optimal, masih terdapat siswa yang kurang serius dalam melaksanakan prakerin.

Kendala di atas dapat berimplikasi baik secara langsung atau tidak langsung pada penguasaan kompetensi produktif teknik kendaraan ringan sebagai syarat mutlak memasuki dunia kerja khususnya dalam bidang otomotif. Hal tersebut berimbas pada rendahnya keterserapan lulusan di industri yang sesuai bidangnya. Melihat kondisi tersebut perlu adanya kajian atau penelitian secara teoritis dan mendalam tentang efektifitas penguasaan kompetensi bidang keahlian dalam mempersiapkan lulusan yang siap kerja atau siap latih. Sehingga dapat memberikan gambaran kepada pihak pengelola SMK khususnya yang membuka bidang keahlian teknik kendaraan ringan tentang pentingnya penguasaan kompetensi bidang keahlian bagi para siswanya. Selain itu, memerlukan suatu analisis yang cermat dalam hal pengaruh kesiapan belajar siswa, prakerin dan motivasi berprestasi. Hal tersebut akan menghasilkan lulusan yang memiliki keterampilan, pengetahuan serta sikap kerja yang baik sesuai bidang keahliannya. 
Tujuan penelitian ini untuk mendefinisikan faktor yang mempengaruhi pencapaian kompetensi mata pelajaran produktif TKR bagi siswa kelas XI di SMK Negeri 1 Jatibarang; mengungkap dan mendeskripsikan tentang motivasi berprestasi, kesiapan belajar siswa, pelaksanaan prakerin dan pencapaian kompetensi mata pelajaran produktif TKR; dan untuk mengetahui seberapa besar pengaruh motivasi berprestasi terhadap kesiapan belajar dan pelaksanaan prakerin dalam upaya pencapaian kompetensi mata pelajaran produktif, khususnya kelas XI; dan untuk mengetahui seberapa besar pengaruh kesiapan belajar dan pelaksanaan prakerin dalam upaya pencapaian kompetensi mata pelajaran produktif TKR kelas XI di SMK Negeri 1 Jatibarang.

Motivasi berprestasi dirumuskan sebagai suatu kesungguhan atau daya dorong seseorang untuk berbuat lebih baik dari apa yang pernah dibuat atau diraih sebelumnya maupun yang dibuat atau diraih orang lain. Motivasi berprestasi termasuk jenis motivasi intrinsik. McClelland (1987), menyebutkan bahwa motivasi berprestasi adalah sebagai suatu usaha untuk mencapai hasil yang sebaik-baiknya dengan berpedoman pada suatu standar keunggulan tertentu (standard of exellence). Kemudian Heckhausen (1967), mengemukakan bahwa motivasi berprestasi merupakan suatu usaha untuk meningkatkan kecakapan pribadi setinggi mungkin dalam segala kegiatannya dengan menggunakan ukuran keunggulan sebagai perbandingan. Jadi, dalam motivasi berprestasi selalu ada kriteria tertentu yang dijadikan tolok ukur kerberhasilan. Dalam hal ini, ada tiga kriteria, yaitu pertama, produk dinilai atas dasar kesempurnaan. Kedua, membandingkan prestasi sendiri yang pernah dicapai sebelumnya. Ketiga, membandingkan dengan prestasi orang lain dalam bidang sejenis.

Manusia pada hakekatnya memiliki kemampuan untuk berprestasi diatas kemampuan yang lain, hal ini dikemukakan oleh David McClelland (Thoha, 2008: 235). McClelland menyebutkan adanya need for achievement disingkat $n$-Ach dan motif berprestasi pada diri individu. Motif berprestasi adalah keinginan untuk berbuat sebaik mungkin tanpa banyak dipengaruhi oleh kebanggaan dan pengaruh sosial, melainkan demi kepuasan pribadinya. Sementara $n$-Ach adalah dorongan untuk mencapai sukses gemilang, hasil yang sebaikbaiknya menurut standar terbaik. Menurut McClelland (Thoha, 2008: 236), seseorang dianggap memiliki motivasi berprestasi jika mempunyai keinginan untuk melakukan sesuatu karya dan prestasi yang lebih baik dari orang lain.

Jadi secara umum motivasi berprestasi adalah kesungguhan atau daya dorong seseorang untuk berbuat lebih baik dari apa yang pernah dibuat atau diraih sebelumnya maupun yang dibuat atau diraih orang lain, yang dapat diukur melalui berusaha untuk unggul dalam kelompoknya, menyelesaikan tugas dengan baik, rasional dalam meraih keberhasilan, 
menyukai tantangan, menerima tanggung jawab pribadi untuk sukses, dan menyukai situasi pekerjaan dengan tanggung jawab pribadi, umpan balik, dan resiko tingkat menengah.

Kesiapan sangat penting untuk memulai suatu pekerjaan, karena dengan memiliki kesiapan, apapun akan dapat teratasi dan dikerjakan dengan lancer dan hasilnya akan jauh lebih baik. Dibawah ini diberikan beberapa pengertian tentang kesiapan. Menurut Sanusi (2005:22), kesiapan merupakan ketersediaan seseorang untuk berbuat sesuatu. Sedangkan menurut Slameto (1995:61), mengemukakan bahwa kesiapan adalah prasyarat untuk belajar bagi seseorang untuk dapat berinteraksi dengan cara tertentu. Kesiapan sangat penting untuk memulai suatu pekerjaan, karena dengan memiliki kesiapan, pekerjaan apapun akan dapat teratasi dan dikerjakan dengan lancar sehingga memperoleh suatu hasil yang baik pula. Kesiapan ini akan menjadi salah satu faktor yang penting dalam pembelajaran berbasis kompetensi. Mengingat dalam rancangan pembelajaran kompetensi menitik beratkan pada pengembangan kemampuan untuk melakukan tugas tertentu yang sesuai dengan standar performansi yang telah ditetapkan. Competency based education is geared toward preparing individuals, to perform identified competency, (Majid, 2005:24).

Kesiapan yang dimaksud dalam penelitian ini adalah kesiapan siswa dalam mengikuti kegiatan pembelajaran di Sekolah Menengah Kejuruan, Khususnya dalam hal pencapaian mata pelajaran produktif atau bidang kompetensi keahlian teknik kendaraan ringan. Belajar merupakan suatu proses dari seorang individu yang berupaya mencapai tujuan belajar atau yang biasa disebut hasil belajar, merupakan bentuk perubahan perilaku yang relatif menetap. Oleh karena itu, untuk mendapatkan hasil belajar yang baik dan maksimal diperlukan persiapan siswa dalam belajar yang baik pula. Persiapan siswa dalam belajar merupakan kebutuhan pokok yang harus dipenuhi oleh siswa dalam mencapai hasil belajar. Djamarah (2002:35), menyatakan bahwa "kesiapan untuk belajar jangan hanya diterjemahkan siap dalam arti fisik, tetapi juga diartikan dalam arti psikis dan materiil”. Kesiapan fisik misalnya kondisi badan yang sehat dan bugar. Kesiapan psikis misalnya ada hasrat untuk belajar, dapat berkonsentrasi, dan ada motivasi instrinsik. Kesiapan materil misalnya ada bahan yang dipelajari atau dikerjakan berupa buku bacaan, catatan pelajaran, modul dan job sheet untuk pembelajaran praktek. Kesiapan siswa dalam belajar merupakan kondisi diri siswa yang telah dipersiapkan untuk melakukan suatu kegiatan belajar. Kesiapan diri siswa akan melahirkan perjuangan untuk mencapai apa yang dicitacitakan.

Praktek kerja industri adalah suatu bentuk penyelenggaraan pendidikan keahlian profesional yang memadukan secara sistematik dan sinkron. Program pendidikan di sekolah dan program penguasaan keahlian yang diperoleh melalui kegiatan langsung di dunia kerja 
secara terarah untuk mencapai suatu tingkat keahlian profesional tertentu (Pakpahan, 1994:7). Melalui penghayatan dalam program praktek kerja industri, siswa akan memperoleh pengalaman bernilai yang akan berpengaruh secara positif terhadap motivasi belajar. Pada akhirnya akan membantu meningkatkan kompetensi sesuai bidang keahliannya (Nolker, 1983:119). Kenyataannya prakerin berbeda dengan PSG, menurut Depdiknas dalam materi pelatihan KTSP 2009 menyatakan bahwa prakerin merupakan program pembelajaran yang harus dilakukan setiap peserta didik di dunia kerja. Prakerin merupakan upaya untuk memperkenalkan lebih dini dunia kerja kepada peserta didik sebagai bagian pengalaman kerjanya. Diharapkan melalui program prakerin siswa mengenal tentang jenis pekerjaan yang ada di lapangan, sikap dan etos kerja, disiplin kerja, dan jenis pekerjaan yang ada di industri. Sehingga siswa bisa memahami perbedaan antara belajar di sekolah dengan kenyataan yang ada di dunia kerja/industri melalui pembelajaran di industri (prakerin).

Pelaksanaan prakerin bukan sekedar penempatan siswa pada industri dan mendapatkan pengalaman bekerja. Namun diharapkan sekolah dapat menyediakan kebutuhan industri akan sumber daya yang memiliki keterampilan dasar. Keterampilan tersebut sebagai modal awal bagi siswa untuk dapat dilibatkan dalam pengalaman kerja dan berinteraksi dengan karyawan lainnya. Lingkup yang akan dijadikan acuan dalam penelitian terkait dengan program prakerin meliputi tahap perencanaan dan persiapan, kesesuaian institusi pasangan dengan bidang kompetensi yang dipelajari. Diperlukan juga, analisis pencapaian kompetensi hasil belajar di sekolah dan dunia kerja serta tahap pelaksanaan sampai dengan evaluasi.

Struktur kurikulum di SMK terdiri dari mata pelajaran normatif, adaptif, dan produktif. Pencapaian kormpetensi produktif dalam pengertian ini terkait dengan penguasaan keterampilan yang akan digunakan dalam memenuhi kompetensi kerja. Mata pelajaran produktif untuk program keahlian teknik kendaraan ringan mengacu kepada Standar Kompetensi Lulusan (SKL) dan Standar Kompetensi Kerja Nasional (SKKNI). Sebagai acuan untuk mengetahui tingkat penguasaan mata pelajaran produktif diambil dari nilai uji kompetensi produktif siswa kelas XI TKR.

\section{METODE}

Penelitian ini merupakan penelitian survey dan berdasar tingkat ekspalanasinya adalah penelitian asosiatif. Penelitian ini dimaksudkan untuk menggambarkan seberapa besar pengaruh motivasi berprestasi terhadap kesiapan belajar dan pelaksanaan prakerin dalam pencapaian kompetensi mata pelajaran produktif teknik kendaraan ringan kelas XI. Lokasi penelitian adalah di Jatibarang, kabupaten Indramayu. Populasi dan sampel penelitian ini adalah seluruh siswa kelas XI TKR SMK N 1 Jatibarang. Instrumen yang digunakan adalah 
berupa angket atau kuesioner. Angket tersebut untuk menjaring data persepsi tentang motivasi berprestasi, kesiapan belajar, pelaksanaan prakerin. Pengujian instrumen dilakukan dengan uji validitas dan reliabilitas. Analisis data yang digunakan adalah statistik inferensial, yaitu teknik statistik inferensial digunakan untuk menganalisis data dengan cara mendeskriptifkan data sebagaimana adanya dan dilanjutkan dengan membuat kesimpulan yang berlaku untuk umum atau generalisasi.

\section{HASIL PENELITIAN}

Berdasarkan hasil analisis statistik dalam penelitian ini didapatkan hasil berupa hubungan yang positif melalui uji koefisien korelasi sebesar 0.786, Peningkatan motivasi berprestasi akan meningkatkan kesiapan belajar siswa, dilihat dari uji determinasi motivasi berprestasi memberikan kontribusi $61.79 \%$ terhadap kesiapan belajar. Melalui pengujian regresi didapatkan persamaan garis regresi adalah $\hat{Y}=8,16+0,83 \mathrm{X}$, konstanta sebesar 8,16 menyatakan bahwa jika tidak ada motivasi berprestasi $(\mathrm{X})$, maka kesiapan belajar $\left(\mathrm{Y}_{1}\right)$ sebesar 8,16. Koefisien regresi sebesar 0,83 menyatakan bahwa setiap penambahan 1 unit motivasi berprestasi $(\mathrm{X})$, maka kesiapan siswa $\left(\mathrm{Y}_{1}\right)$ akan meningkat sebesar 0,83 .

Motivasi berprestasi terhadap pelaksanaan prakerin dalam penelitian ini mmenunjukkan hubungan yang positif melalui uji koefisien korelasi sebesar 0,678. Peningkatan motivasi berprestasi akan berkorelasi secara positif terhadap pelaksanaan prakerin, dilihat dari uji determinasi motivasi berprestasi memberikan kontribusi 45,94\% terhadap pelaksanaan prakerin. Melalui pengujian regresi didapatkan persamaan regresi yaitu $\hat{Y}=13,99+0,74 \mathrm{X}$, konstanta sebesar 13,99 menyatakan bahwa jika tidak ada motivasi berprestasi $(\mathrm{X})$, maka pelaksanaan prakerin $\left(\mathrm{Y}_{2}\right)$ sebesar 13,99. Koefisien regresi sebesar 0,74 menyatakan bahwa setiap penambahan 1 unit motivasi berprestasi (X), maka pelaksanaan prakerin $\left(\mathrm{Y}_{2}\right)$ akan meningkat sebesar 0,74.

Sedangkan hubungan kesiapan belajar dengan pencapaian kompetensi mata pelajaran produktif dalam penelitian ini didapatkan hasil berupa hubungan yang positif melalui uji koefisien korelasi sebesar 0,39. Peningkatan kesiapan belajar siswa akan berkorelasi secara positif terhadap pencapaian kompetensi mata pelajaran produktif kelas XI menjadi lebih baik, dilihat dari uji determinasi kesiapan belajar memberikan kontribusi sebesar 15,31\% . Melalui pengujian regresi didapatkan persamaan regresi adalah $\hat{Z}=74,39+0,11 \mathrm{Y}_{1}$, konstanta sebesar 74,39 menyatakan bahwa jika tidak ada kesiapan belajar ( $\left.\mathrm{Y}_{1}\right)$, maka pencapaian kompetensi mata pelajaran produktif kelas XI (Z) sebesar 74,39. Koefisien regresi sebesar 0,11 menyatakan bahwa setiap penambahan 1 unit kesiapan belajar $\left(\mathrm{Y}_{1}\right)$, maka pencapaian kompetensi mata pelajaran produktif kelas XI (Z) akan meningkat sebesar 0,11. 


\section{PEMBAHASAN}

Berdasarkan hasil analisis statistik dalam penelitian ini didapatkan bahwa hubungan antara pelaksanaan prakerin dengan pencapaian kompetensi mata pelajaran menunjukkan korelasi sebesar 0,378. Memberikan kontribusi sebesar 14,26\% dalam pencapaian kompetensi mata pelajaran produktif. Melalui pengujian regresi didapatkan persamaan regresi adalah $\hat{Z}=$ $74,60+0,1 Y_{2}$, konstanta sebesar 74,60 menyatakan bahwa jika tidak ada pelaksanaan prakerin $\left(\mathrm{Y}_{2}\right)$, maka pencapaian kompetensi mata pelajaran produktif kelas $\mathrm{XI}(\mathrm{Z})$ sebesar 74,60. Koefisien regresi sebesar 0,1 menyatakan bahwa setiap penambahan 1 unit pelaksanaan prakerin $\left(\mathrm{Y}_{2}\right)$, maka pencapaian kompetensi mata pelajaran produktif kelas XI (Z) akan meningkat sebesar 0,1.

Motivasi berprestasi memiliki pengaruh yang positif dalam menunjang kesiapan belajar siswa. Motivasi belajar merupakan keseluruhan daya penggerak di dalam diri siswa yang menimbulkan kegiatan belajar. Hal ini menjamin kelangsungan dari kegiatan belajar dan yang memberikan arah pada kegiatan belajar, sehingga tujuan yang dikehendaki dapat tercapai. Di dalam kegiatan belajar motivasi merupakan faktor yang sangat penting. Motivasi memberi dorongan yang menggerakkan seseorang untuk melakukan suatu kegiatan. Motivasi merupakan pengarah untuk kegiatan belajar kepada tujuan yang jelas yang diharapkan dapat tercapai. Ciri-ciri siswa yang memiliki motivasi pada dirinya antara lain siswa tersebut tekun menghadapi tugas, ulet menghadapi kesulitan, lebih mandiri, dapat mempertahankan pendapatnya, senang dan dapat memecahkan permasalahan yang dihadapinya.

Motif berprestasi akan memberikan dampak positif terhadap kemajuan belajar siswa, yang diwujudkan melalui kesungguh dalam mempersiapkan kegiatan pembelajaran. Motivasi berprestasi juga mempunyai kaitan yang positif dalam menunjang keberhasilan prakerin bagi siswa. Dengan demikian motif berprestasi akan mendorong siswa bersungguh-sungguh dalam melaksanakan prakerin. Semakin tinggi motif berprestasi siswa dalam melaksanakan prakerin, maka hasil pelaksanaan prakerin juga makin baik, hal akan membantu siswa dalam menguasai kompetensi yang dibutuhkan didunia kerja.

Motif berprestasi dapat berasal dari dalam diri individu dan dari luar diri individu. Dalam diri individu dapat berupa pengaruh metabolisme dari dalam tubuh. Sedangkan dari luar diri individu dapat berupa pengaruh keluarga yang menghargai kesuksesan dan mendorong anaknya untuk berprestasi. Prestasi belajar adalah hasil belajar yang dicapai individu setelah melalui proses belajar. Kesiapan untuk belajar adalah kondisi yang mendahului belajar, tanpa kesiapan proses belajar tidak akan lancer. Hal tersebut disebabka untuk memasuki kancah pendidikan dengan berhasil harus melalui berbagai syarat yang berkaitan dengan kemampuan dan kesiapan baik yang bersifat biologis maupun psikologis. 
Seseorang akan berhasil dalam belajar apabila memiliki kesiapan yang baik. Dengan demikian, akan terhindar dari perasaan terpaksa dalam melakukan sesuatu tugas. Kesiapan belajar siswa memberikan pengaruh yang positif terhadap pencapaian kompetensi mata pelajaran produktif. Makin tinggi kesiapan belajar siswa, maka akan berdampak pada hasil pencapaian kompetensi mata pelajaran produktif TKR menjadi lebih baik.

Pelaksanaan prakerin juga berpengaruh secara positif terhadap pencapaian kompetensi mata pelajaran produktif kelas XI. Hal ini dapat diindikasikan dari hasil uji kompetensi bagi siswa yang serius dalam mengerjakan prakerin menunjukkan hasil yang cukup signifikan. Pelaksanaan prakerin yang tepat sasaran juga membantu siswa dalam memahami kompetensi yang diperlukan dalam bekerja. Oleh karena itu, pihak sekolah agar melakukan kajian lebih lanjut tentang arah kerjasama dengan industri agar terbentuk pola yang jelas dan tepat sasaran. Dimana arah kerjasama bisa berbentuk prakerin, PSG, atau menerapkan teaching factory.

Siswa setelah memperoleh pengetahuan secara teori dan praktik (dasar keterampilan). Selanjutnya dilatih secara efektif dalam lingkungan industri sehingga menjadi tenaga yang siap kerja. Pelatihan atau belajar di lingkungan industri memungkinkan siswa menerapkan pengetahuan yang telah diperolehnya di sekolah. Pengetahuan yang relevan dengan lapangan pekerjaan akan memudahkan siswa untuk beradaptasi dengan lingkungan industri, baik dengan pekerjaan yang akan dilakukannya maupun dengan personel industri.

Dalam menuju masyarakat industri, kebutuhan tenaga kerja yang terampil, kreatif, dan produktif merupakan tuntutan yang wajar. Hal tersebut, karena perkembangan teknologi industri yang semakin cepat dan canggih perlu diimbangi dengan tersedianya tenaga kerja yang mempunyai kualifikasi sesuai dengan kebutuhan tersebut. Upaya untuk memperoleh tenaga kerja dengan kualitas memadai, maka program pendidikan perlu mengimbangi dengan peningkatan mutu lulusannya. Hal tersebut ditentukan adanya keberhasilan proses belajar mengajar dan terhubungnya dengan dunia usaha dan dunia industri sebagai pengguna lulusan. Kegiatan proses belajar mengajar pada dasarnya adalah proses perilaku yang dirancang secara sengaja dan sadar menuju tercapainya suatu tujuan tertentu, yaitu tujuan pendidikan. Sejalan dengan tujuan pendidikan kejuruan sebagai program pendidikan yang berkait langsung dengan penyiapan seseorang untuk memasuki dunia kerja atau peningkatan persiapan bagi tuntutan karir yang lebih tinggi. Sehingga pendidikan yang terhubung dengan dunia usaha dan dunia industri sangat memainkan peranan penting. Hal tersebut sebagai proses transformasi bebagai perkembangan teknologi baik yang sedang digunakan maupun terhadap antisipasi perubahan teknologi dimasa datang yang kian cepat. 
Tujuan dan kebutuhan yang akan dicapai individu sebaiknya mempunyai relevansi dengan kehidupan masyarakat atau lapangan pekerjaan (dunia kerja). Pengalaman kerja akan memberikan bekal tentang, arti kerja, adanya perbedaan pekerjaan, mencoba kemampuan, pengembangan minat, pengembangan tingkah laku dan sifat kerja yang dapat diterima, serta belajar mencari uang (nafkah). Sedangkan dalam perspektif instrumental, pendidikan dipandang sebagai instrumen perubahan sosial yang progresif. Dengan misi utama menciptakan relevansi pendidikan dengan kebutuhan dunia kerja atau pemakai. Perubahan sosial yang progresif dalam masyarakat menghendaki adanya antisipasi bidang pendidikan. Untuk mengimbangi perubahan tersebut dengan memperhatikan kemajuan dan perkembangan IPTEK.

Berkenaan dengan relevansi pendidikan dengan kebutuhan dunia kerja atau pemakai adanya pendidikan yang sesuai dengan jabatan yang akan dipegangnya. Pendidikan harus berorientasi pada tugas, yakni tugas-tugas aktual yang relevan dengan kehidupan masyarakat. Adanya relevansi antara pendidikan dan tugas-tugas dapat meningkatkan kinerja masyarakat, sebab faktor lain yang mempengaruhi pekerjaan adalah pengetahuan. Jelas, bahwa lembaga pendidikan khususnya untuk sekolah menengah kejuruan mempunyai peran yang besar dalam mempersiapkan generasi muda untuk terjun dalam kehidupan masyarakat.

\section{KESIMPULAN}

Motivasi berprestasi memiliki pengaruh yang positif dalam menunjang kesiapan belajar siswa. Dengan demikian, motif berprestasi akan memberikan dampak positif terhadap kemajuan belajar siswa, yang diwujudkan melalui kesungguhan dalam mempersiapkan kegiatan pembelajaran. Motivasi berprestasi juga mempunyai kaitan yang positif dalam menunjang keberhasilan prakerin bagi siswa. Kesiapan belajar siswa memberikan pengaruh yang positif terhadap pencapaian kompetensi mata pelajaran produktif, semakin tinggi kesiapan belajar siswa, maka akan berdampak pada hasil pencapaian kompetensi. Pelaksanaan prakerin berpengaruh secara positif terhadap pencapaian kompetensi mata pelajaran produktif. Hal ini dapat diindikasikan dari hasil uji kompetensi bagi siswa yang serius dalam mengerjakan prakerin menunjukkan hasil yang cukup signifikan.

\section{DAFTAR PUSTAKA}

Bailey. T, et al. (2004). Working Knowledge: Work Based Learning and Education Reform. New York: Routledge Falmer.

Depdiknas, (2003), Pedoman Pelaksanaan Praktek Kerja Industri (SMK). Jakarta: DPMK. Dimyati, dan Mudjiono. (2002). Belajar dan Pembelajaran. Jakarta: PT. Rineka Cipta 
Direktorat Dikmenjur. (2006). Buku Kurikulum SMK Edisi 2006. Jakarta: DPMK

Direktorat Jenderal Pendidikan Menengah Kejuruan. (2002). Sejarah Pendidikan Teknik dan Kejuruan di Indonesia: Membangun Manusia Produktif. Jakarta: Depdiknas.

Djamarah, Syaeful. (2002). Prestasi Belajar dan Kompetensi Guru. Jakarta: Usaha Nasional.

Djojonegoro, W. (1998). Pengembangan Sumber Daya Manusia: Melalui Sekolah Menengah Kejuruan. Jakarta: Depdikbud.

Direktorat Dikmenjur. (2004). Kurikulum Teknik Mekanik Otomotif Edisi 2004. Jakarta: Depdiknas.

Evarinayanti. (2002). Pelatihan Berbasis Kompetensi (Competency Based Training). Jakarta: Depdiknas.

Fudyartanto, Ki. (2002). Psikologi Pendidikan dengan Pendekatan Baru. Yogyakarta: Global Pustaka Ilmu.

Hamalik, Oemar. (2004). Proses Belajar Mengajar. Jakarta: PT Bumi Aksara

Mulyasa, E. (2004). Kurikulum Berbasis Kompetensi Konsep, Karakteristik dan Implementasi. Bandung: PT. Remaja Rosdakarya.

Mulyasa, E. (2005). Implementasi Kurikulum 2004, Panduan Pembelajaran KBK. Bandung: PT Remaja Rosdakarya.

Siregar, Evaline dan Nara, Hartini (2010), Teori Belajar dan Pembelajaran. Bogor: Ghalia Indonesia.

Sukmadinata, N.S. (2001). Pengembangan Kurikulum Teori dan Praktek. Bandung: PT Remaja Rosdakarya.

Sukmadinata, N.S. (2004). Kurikulum dan Pembelajaran Kompetensi. Bandung: Yayasan Kesuma Karya

Uno, B. Hamzah. (2010). Teori Motivasi dan Pengukurannya. Jakarta: PT. Bumi Aksara. 